\title{
Proses Dokumentasi Keperawatan: Gangguan Persepsi Sensori Halusinasi Pendengaran pada Skizofrenia
}

\author{
Elina Aris Tiyani ${ }^{1}$, Dian Prastiwi ${ }^{1}$, Angga Sugiarto ${ }^{1}$ \\ Poltekkes Kemenkes Semarang \\ Correspoding author: aris.elina24@gmail.com
}

\begin{abstract}
ABSTRAK
Latar belakang: Skizofrenia adalah psikosis, jenis penyakit mental yang ditandai dengan distorsi dalam berpikir, persepsi, emosi, bahasa, rasa diri dan perilaku. Salah satu gejalanya adalah halusinasi yaitu mendengar, melihat atau merasakan hal-hal yang tanpa adanya rangsangan eksternal. Gangguan persepsi sensorik ini mencakup semua panca indera.Salah satunya halusinasi pendengaran.

Tujuan: menggambarkan penerapan proses asuhan Keperawatan jiwa dengan gangguan persepsi sensori halusinasi pendengaran Ny.F di RSJ Prof.Dr. Soerojo Magelang.

Metode: penelitian ini dilakukan dengan menggunakan metode deskriptif. Pengambilan data dengan wawancara dan observasi pada proses keperawatan pada pasien halusinasi pendengaran.

Hasil: terdapat peningkatan pengetahuan dan kemampuan mengontrol halusinasi,

Kesimpulan: asuhan keperawatan pada pasien skizofrenia dengan halusinasi dapat meingkatan pengetahuan dan kemampuan mengontrol halusinasi.
\end{abstract}

Kata kunci:

Asuhan keperawatan jiwa; halusinasi; skizofrenia.

\section{ABSTRACT}

Background: Schizophrenia is a psychosis, a type of mental illness characterized by distortions in thinking, perception, emotion, language, sense of self and behavior. One of the symptoms is hallucinations, hallucinations: hearing, seeing or feeling things in the absence of external stimuli. This sensory perception disorder includes all five senses. One of them is auditory hallucinations.

Objective: to describe the implementation of the nursing process for mental health with impaired sensory perception, auditory hallucinations, Mrs. F at Prof.Dr. Soerojo Magelang.

Methods: this research was conducted using a descriptive method. Collecting data by interview and observation on the nursing process in patients with auditory hallucinations.

Results: there was an increase in knowledge and ability to control hallucinations,

Conclusion: Nursing care for schizophrenic patients with hallucinations can increase knowledge and ability to control hallucination.

\section{Keywords:}

Psychiatric nursing care; hallucinations; schizophrenia. 


\section{PENDAHULUAN}

Gangguan jiwa merupakan salah satu masalah kesehatan yang membutuhkan perhatian. Gangguan, dibagi menjadi dua bagian yaitu gangguan jiwa berat/kelompok psikotik, dan gangguan jiwa ringan, meliputi semua masalah mental dan emosional yang berupa gangguan kecemasan, panik, dan mood (Riskesdas, 2013). Menurut data Riskesdas (2018) gangguan psikologis mulai ada pada usia muda (15-24 tahun) dengan angka prevalensi $6,2 \%$. Prevalensi stres mental terus meningkat seiring bertambahnya usia, dengan $8,9 \%$ pada usia di atas 75 tahun, $8,0 \%$ pada usia $65-74$ tahun dan $6,5 \%$ pada usia 55-64 tahun. Dalam hal ini menunjukkan bahwa prevalensi tertinggi adalah pada usia 75 tahun ke atas.

Skizofrenia adalah gangguan mental kronis dan parah yang mempengaruhi 20 juta orang di seluruh dunia (GBD Collaborator, 2018). Orang dengan skizofrenia 2-3 kali lebih mungkin meninggal lebih awal daripada populasi umum (Laursen, Nordentoft, dan Mortensen, 2014) Hal ini sering disebabkan oleh penyakit fisik yang dapat dicegah, seperti penyakit kardiovaskular, penyakit metabolik, dan infeksi (WHO, 2019). Lebih dari $69 \%$ orang dengan skizofrenia tidak menerima perawatan yang tepat (Lora et al, 2012). Di Indonesia prefalensi skixzofrenia/psikosis mencapai 7 per mil di pedesaan dan 6,4 per mil di perkotaan (Pusdatin Kemenkes, 2019). Salah satu gejala skizofrenia adalah halusinasi (WHO, 2019).

\section{TUJUAN}

Menggambarkan penerapan proses asuhan Keperawatan jiwa dengan gangguan persepsi sensori halusinasi pendengaran Ny.F di RSJ Prof.Dr.Soerojo Magelang.

\section{METODOLOGI PENELITIAN}

Metode yang digunakan dalam penelitian ini adalah metode deskriptif, yaitu dengan menjabarkan atau menggambarkan proses keperawatan paparan kasus yang meliputi pengkajian, diagnosis, intervensi, implementasi dan evaluasi. Penelitian ini, dilakukan di RSJ Prof.Dr.Soerojo Magelang pada tanggal 10 sd 12 Mei 2021. Dalam penelitian ini terdapat satu responden (klien), klien berusia 34 tahun yang secara medis didiagnosa sebagai Skizofrenia paranoid. Pengumpulan data melalui wawancara dan observasi terhadap responden.

\section{HASIL}

Klien bernama Ny.F, berjenis kelamin perempuan, usia 34 tahun ,agama islam serta sudah menikah. Klien masuk rumah sakit jiwa magelang tanggal 7 mei 2021 dengan diagnosis medis F.20.0 yaitu skizofrenia paranoid. Alasan klien di bawa ke rumah sakit sebab marah yang tidak terkendali serta klien melihat bayangan dan mendengar suarasuara.

Faktor predisposisi dari Ny.F merasa kehilangan suami dan anaknya yang sudah meninggal dunia. Dalam keluarga klien ada riwayat gangguan jiwa yaitu ibu klien karena stress.klien merasa dirinya hanya sendirian di dunia ini bersumber pengkajian bahwa Ny.F merasa malu untuk bergaul di lingkungan sekitarnya dan klien merasa dirinya jelek serta tidak berguna. Saat di lakukan wawancara klien kooperatif dan mau 
menjawab pertanyaan-pertanyaan yang diajukan. Klien mengalami halusinasi pendengaran, dan klien mengatakan mendengar suara-suara yang seperti suara anaknya yang sudah meninggal, klien merasa terganggu dengan suara yang kadang-kadang muncul saat klien sedang melamun. Klien

Berdasarkan pengkajian yang dilakukan tanggal 10 mei 2021 pada Ny.F dihasilkan Analisa data yaitu: Data Subjektif (DS) klien mengungkapkan jika sedang melamun klien acapkali mendengar bunyi-bunyi yang menganggu klien semacam bisikan yang mengungkapkan"mak,saya kangen, kesini mak" dengan frekuensi kadang-kadang ketika bunyi itu timbul klien menjadi tegang dan khawatir. Data Objektif (DO) klien seperti tegang,gelisah,tidak tenang dan suka mondar-mandir.

Kemudian diagnosis keperawatan yang di dapat dari pengkajian yang telah dilakukan kepada Ny,F yaitu gangguan persepsi sensori halusinasi pendengaran. Tindakan keperawatan yang dilakukan Ny.F pada tanggal 10 mei 2021 memiliki tujuan dan rencana tindakan keperawatan untuk mengatasi halusinasi pendengaran yang dialami klien, tujuanya yaitu klien dapat mengenali,mengontrol dan memutuskan halusinasinya.Sedangkanrencana.tindakan keperawatan yang dilakukan pada tanggal 10-12 mei 2021 diantaranya:identifikasijenis,isi,waktu, frekuensi halusinasi klien;Kenali kondisi yang menyebabkan halusinasi; kenali reaksi pasien dan ajarkan teguran;memasukkankejadwal;melibatkan pasien dalam TAK (terapi aktifitas kellompok); evaluasi jadwal kegiatan sehari-hari pasien; ajar klien kendalikan halusinasi dengan 5 benar minum obat;dan ajar klien kendalikan halusinasi dengan berbicara dengan orang lain.

Hasil evaluasi pada tanggal 10 mei 2021 yang di dapatkan setelah melakukan rencana keperawatan diatas didapatkan data subjektif: klien berkata halusinasi yang muncul berupa suara yang muncul saat melamun. Jika halusinasi muncul. Data objektif: klien tampak gelisah,tegang. Klien mampu mengulangi dan mempraktekkan cara menghardik halusinasi dengan benar, setelah melakukan tindakan keperawatan dengan cara menghardik klien tampak rileks. Analisa: masalah keperawatan teratasi sebagian. Perencanaan: melanjutkan intervensi seperti: membina interaksi saling percaya, mengadakan kontak sering pada responden, mengidentifikasi Bersama klien waktu munculnya halusinasi dan frekuensi halusinasi dan mengidentifikasi tindakan yang bisa dilakukan apabila halusinasinya muncul.

Evaluasi pada tanggal 11 mei 2021 didapatkan data subjektif: klien mengatakan bias mengatasi halusinasi muncul dengan menghardik, dan klien mengungkapkan bersedia diajarkan mengontrol halusinasi dengan 5 benar minum obat. Data objektif: klien kooperatif,mampu menyebutkan serta mempraktikkan cara mengontrol halusinasi dengan cara menghardik klien. Analisa:masalah teratasi sebagian. Perencanaan: melanjutkan intervensi dengan membina hubungan saling percaya,mengadakan kontak langsung yang senang dengan klien, dan mengidentifikasi tindakan yang bisa dilakukan ketika halusinasinya muncul 
Evaluasi pada tanggal 13 mei 2021 data subjektif: klien mengatakan masih ingat dengan nama perawat, tidak lupa cara mengontrol halusinasi yang sudah diajarkan yaitu menghardik dan 5 benar minum obat, klien juga bersedia diajarkan cara yang ketiga yaitu berinteraksi dengan orang lain. Data objektifnya: klien kooperatif, dapat menyebutkan cara mengendalikan halusinasi dan cara yang baru diajarkan. Analisis: masalah teratasi sebagian. Perencanaan: lanjutkan intervensi yang sudah diajarkan.

\section{PEMBAHASAN}

Respon yang di tunjukkan klien ketika dilakukan proses keperawatan yaitu klien menunjukkan penerimaan ketika berkomunikasi dengan perawat dan kooperatif saat dilakukan tindakan keperawatan. Komunikasi terapeutik memberikan dampak terhadap kepuasan pasien (Aswad, Mulyadi, Lolong, 2015), penurunan kecemasan (Batubara, 2015), dan kepuasan pasien (Kusumo, 2017).

Dari data pengkajian, menggunakan Standard Diagnosis Keperawatan Indonesia (2017) dirumuskan diagnosa gangguan persepsi sensori halusinasi pendengaran. Pusdiklatnakes (2012) merekomendasikan tanda dan gejala halusinasi dinilai dari pengamatan dan ekspresi wajah, misalnya mengatakan mendengar suara bisikan, mendengar suara yang merangsang dialog, dan mendengar suara berbicara kepada mereka. melakukan beberapa hal berbahaya, mereka melihat bayangan, cahaya, bentuk geometris, telah melihat hantu dan monster.

Menurut hasil pengkajian di dapatkan faktor predisposisi klien adalah klien di tinggalkan oleh suami dan anak-anaknya karena meninggal dunia dan klien merasa kalau dirinya hanya sendirian di dunia. Ibu klien juga mempunyai riwayat gangguan jiwa dan sudah meninggal karena stress. Predisposisi meliputi faktor biologis (Dalami, 2014), koping maladaptif (Hartanti \& Pratiwi, 2018), kehilangan, kegagalan, dan berduka (Pratiwi, Widodo, Jadmiko).

Perawat melakukan implementasi identifikasi jenis, isi, waktu, frekuensi halusinasi klien; identifikasi situasi yang menimbulkan halusinasi; identifikasi respon pasien,mengajarkan menghardik; memasukkan kejadwal; melibatkan pasien dalam TAK (terapi aktifitas kelompok); evaluasi jadwal harian pasien; latih pasien mengendalikan halusinasi dengan 5 benar minum obat; dan latih pasien mengendalikan halusinasi dengan bercakap-cakap dengan orang lain. Hal ini di sesuai dengan pernyataan bahwa intervensi keperawatan yang dapat diberikan pada partisipan dengan halusinasi yaitu membantu partisipan mengenali halusinasi, melatih partisipan mengontrol halusinasi , strategi pelaksanaan latihan cara menghardik halusinasi, strategi pelaksanaan ,minum obat secara teratur, strategi pelaksanaan latihan berinteraksi dengan orang lain, strategi pelaksanaan melakukan aktivitas sehari-hari (Keliat, 2014)

Evaluasi yang dilaksanakan setiap selesai intervensi menunjukkan hasil yang baik. Penilaian pada tanda gejala dan kemampuan pasien. Evaluasi adalah proses berkelanjutan yang digunakan untuk mengevaluasi dampak kegiatan keperawatan terhadap peserta, dan evaluasi didasarkan pada kegiatan keperawatan yang dilakukan Afnuhazi (2015). Asuhan keperawatan pada pasien halusinasi berpengaruh terhadap 
kemampuan pasien mengontrol halusinasi (Samal, Ahmad, dan Saidah, 2018), dan efektif diberikan kepada pasien halusinasi (Aldan \& Wardani, 2019).

\section{KESIMPULAN}

Sebelum diterapkan tindakan pada Ny.F klien selalu mondar-mandir,tegang dan gelisah saat halusinasinya muncul karena klien masih belum mengetahui cara mengontrol halusinasinya, klien jarang berinteraksi dengan orang lain tetapi mau berinteraksi dan mau mengikuti kegiatan yang di instruksikan oleh perawat. Setelah dilakukan asuhan keperawatan pada klien respon yang di tunjukkan oleh klien kooperatif, mau diajak berdiskusi oleh perawat, mau berinteraksi dengan orang lain dan klien lebih ada kemauan untuk sembuh dari penyakitnya, hal ini di buktikan oleh klien yang mengalami peningkatan pengetahuan dan kemampuan mengendalikan halusinasinya yaitu, dengan cara menghardik minum obat dan berinteraksi dengan orang lain.

\section{REFERENSI}

Afnuhazi, R. (2015). Komunikasi Terapeutik Dalam Keperawatan Jiwa. Yogyakarta: Gosyen Publising.

Aswad, S., Mulyadi, Lolong, J. J. S., (2015). Hubungan Komunikasi Terapeutik Perawat Dengan Kepuasan Pasien, Ejournal Keperawatan, https://ejournal.unsrat.ac.id/index.php/jkp/article/download/8086/7647

Batubara, I., Komunikasi Terapeutik Pada Pasien Pre Oparatif Efektif Menurunkan Tingkat Kecemasan Pasien, Jurnal Ilmiah PANMED, http://ojs.poltekkes-medan.ac.id/pannmed/article/download/221/184

Dalami E, dkk. (2014). Asuhan Keperawatan Klien Dengan Gangguan Jiwa. Jakarta: CV. Trans Info Media.

GBD 2017 Disease and Injury Incidence and Prevalence Collaborators. (2018). Global, regional, and national incidence, prevalence, and years lived with disability for 354 diseases and injuries for 195 countries and territories, 1990-2017: a systematic analysis for the Global Burden of Disease Study 2017. The Lancet; (https://doi.org/10.1016/S0140-6736(18)32279-7).

Keliat, B.A Dkk.(2014). Model Keperawatan Profesional Jiwa, Jakarta : EGC

Kusumo, M. P., (2017). Pengaruh Komunikasi Terapeutik Perawat Terhadap Kepuasan Pasien di Rawat Jalan RSUD Jogja, Jurnal Medicoeticolegal dan Manajemen Rumah Sakit, https://core.ac.uk/download/pdf/193255193.pdf

Laursen TM, Nordentoft M, Mortensen PB. (2014) Excess early mortality in schizophrenia. Annual Review of Clinical Psychology Journal ;10, 425-438. https://doi.org/10.1146/annurev-clinpsy-032813-153657

Lora, A, Kohn, R., Levav, I., McBain, R., Morris, J., Saxena, S., (2012). Service availability and utilization and treatment gap for schizophrenic disorders: a survey in 50 low- and middle-income countries. Bulletin World Health Organisation 10.2471/BLT.11.089284. https://doi.org/10.2471/BLT.11.089284

Pusdatin Kemenkes. (2019). Situasi Kesehatan jiwa di Indonesia. Infodatin https://pusdatin.kemkes.go.id/download.php?file=download/pusdatin/infodatin/I nfoDatin-Kesehatan-Jiwa.pdf

Pusdiklatnakes. (2012). Modul Pelatihan Keperawatan Kesehatan Jiwa Masyarakat. Jakarta: Badan PPSDM Kesehatan. 
Samal, M.H., Ahmad, A.K., Saidah, S., (2018). Pengaruh Penerapan Asuhan Keperawatan Pada Klien Halusinasi Terhadap Kemampuan Klien Mengontrol Halusinasi Di RSKD Provinsi Sulawesi Selatan. Jurnal ilmiah Kesehatan Diagnossis, http://ejournal.stikesnh.ac.id/index.php/jikd/article/view/839 WHO.(2019).Schizophrenia. https://www.who.int/news-room/fact-sheets/detail /schizophrenia 